\title{
PROP̈OSALS FOR CARRYING THE MAIL IN THE STATE OF IOWA
}

(From the [Ottumwa] Des Moines Courier, May 24, 1850.)

Extract from the act of Congress of March 3, 1845, section 18.

"And be it further enacted that it shall be the duty of the Postmaster General, in all future lettings of contracts for the transportation of the mail, to let the same, in every case, to the lowest bidder tendering sufficient guaranties for faithful performance, without reference to the mode of such transportation that may be necessary to provide for the due celerity, certainty, and security of such transportation; nor shall any new contractor hereafter be required to purchase out, or take at a valuation, the stock or vehicles of any previous contractor for the same route."

Bidders will be careful to read the forms and instructions appended to this advertisement. They are requested to state, in their proposals, the mode by which they intend to convey the mail. Where the size and weight of the mails, or the speed called for in the schedules shall require it, the contracts will be made for coach, steamboat, or railroad conveyance, as the case may be; and, consequently, such routes will be let to bids proposing such mode of conveyance. In all other cases, the routes will be assigned to bids proposing the cheapest mode of transportation.

Railroad companies are specally notified that their regular bids are to be understood as including the supply of each office on the line of their respective roads not over a quarter of a mile from their depot. Separate proposals for offices more than a quarter of a mile off will be considered.

Proposals for carrying the mails of the United States from the 1st day of July, 1850, to the 30th of June, 1854, inclusive, in the STATE OF IOWA, will be received at the Contract Officc of the Post Office Department, in the city of Washington, until 10 A. M. of the 16th day of April, 1850, (to be decided by the 11th day of May, 1850,) on the routes and in the manner and time herein specified, viz: 


\section{IOWA : ${ }^{1}$}

4651 From Keokuk at 4 a $\mathrm{m}$ tri-weekly, Monday, Wednesday, and Friday;

By Van Buren, Farmington, Bonaparte, Bentonsport, Keosauqua, Winchester, and Birmingham;

To Fairfield by $10 \mathrm{p}$ m, 75 miles;

And back between $4 \mathrm{a} \mathrm{m}$ and $10 \mathrm{p} \mathrm{m}$ next days.

Proposals for six times a week service will be considered.

4652 From Keokuk at 4 a m once a week; Tuesday;

By Prairie House, ${ }^{2}$ Salem, and Glasgow;

To Fairfield by $12 \mathrm{~m}$ next day, 60 miles;

And back between $1 \mathrm{p} \mathrm{m}$ Wednesday and $6 \mathrm{p}$ in next day.

Proposals to commence at West Point will be considered.

4653 From Keokuk at 4 a m daily, except Sunday;

By Summitsville, Montrose, Fort Madison, and Green Bay;

To Burlington by $3 \mathrm{p} \mathrm{m}, 45$ miles;

And back between 11 a in and $10 \mathrm{p} \mathrm{m}$.

Proposals to extend this route and service to Muscatine will be considered.

1654 From Fort Madison at 1 p m tri-weckly, 'Tuesday, Thursday, and Saturday;

By West Point. Tusearora, and Primrose;

To Farmington by $11 \mathrm{p} \mathrm{m,} 29$ miles;

And back between 6 a $\mathrm{m}$ and $4 \mathrm{pm}$, Monday, Wednesday, and Friday.

4655 From Montrose, Iowa, at 6 a $\mathrm{m}$ once a week Saturday;

By String Prairie, Montrose, and St. Francisville, Mo.;

To Waterloo by $12 \mathrm{~m}, 19$ miles;

And back between $2 \mathrm{p}$ m and nine $\mathrm{p} \mathrm{m}$.

4656 From Montrose at 6 a $\mathrm{m}$ twice a week, Wednesday and Saturday;

By Prairie House, Franklin Centre, West Point, and Lowell;

To Mount Pleasant by $6 \mathrm{p} \mathrm{m,} 36$ miles;

And back between 6 a $\mathrm{m}$ and $6 \mathrm{p}$ m 'Tuesday and Friday.

Proposals for tri-weekly service will be considered.

4657 From Burlington at $1 \mathrm{p} \mathrm{m}$ once a week, Tuesday;

By Parrish, Lowell, East Grove, Salem, Hillsboro', and Union;

'To Keosauqua by $6 \mathrm{p}$ m next day 53 miles;

And back between 6 a m Monday and 11 a m next day.

1We have copied this article as it appears in the Courier, using their capitalization, punctuation, and old-fashioned spelling apparent in some of the names of post offices.

2 Prairie House, the name of the post office at the present village and railroad station of Charleston, Lee County. from 1843 to 1850 , when it was clanged to Charleston. See ANNals of lowa, Vol. XVII, page 587. Nearly all the names of these post offices which are not on present day maps are to be found in articles on "Abandoned Towns, Villages and Post Offices of Iowa" published in the issues of the ANNals of October, 1930; Janulary, April. July, and October, 1931, with an index in January, 1032. 'They are in Vols. XVII and XVII. 
4658 From Burlington at 4 a $\mathrm{m}$ daily, except Sunday;

By Middletown, Hartford, New London, Mount Pleasant, Rome and Lockridge;

To Fairfield by $8 \mathrm{p} \mathrm{m}, 50$ miles;

And back between 4 a $\mathrm{m}$ and $8 \mathrm{p} \mathrm{m}$.

4659 From Burlington at $4 \mathrm{p} m$ daily except Sunday;

By Navarre, Yellow Springs, Linton, Wapello and Grandview;

To Museatine by 11 a $\mathrm{m}$ next days, 53 miles;

And back between $2 \mathrm{p} \mathrm{m}$ and 10 a m next days.

4660 From Burlington at 6 a $\mathrm{m}$ once a week, Saturday;

By Albright's, Bluff Dale, Hawk Eye, and Palo Alto;

To 'Tuolsboro' by $3 \mathrm{p} \mathrm{m}, 26$ miles;

And back between $9 \mathrm{a} \mathrm{m}$ and $6 \mathrm{p} \mathrm{m}$ Friday.

4601 From Navarre at 9 a $\mathrm{m}$ once a week, Tuesday,

By Virginia Grove, Hope Farm, Columbus City, Port Allen, and

Seventy-seven,

To Iowa city by 6 p m next day;

And back between 6 a $\mathrm{m}$ Thursday and $4 \mathrm{p}$ m next day.

4662 From Wapello, Iowa, at 6 a $\mathrm{m}$ once a week, Wednesday;

- By 'Toolsboro';

To New Boston, 1ll., by $12 \mathrm{~m}, 12$ miles,

And back between $4 \mathrm{p} \mathrm{m}$ and $10 \mathrm{p} \mathrm{m}$.

4663 From Wapello at 8 a $\mathrm{m}$ once a week, Tuesday,

By Hope Farm, Crawfordsville, and Pottsville,

To Washington by $6 \mathrm{p} \mathrm{m}, 30$ miles;

And back between 6 a m Wednesday and $4 \mathrm{p} \mathrm{m}$.

4664. From Muscatine at $12 \mathrm{~m}$ daily, except Sunday;

By Fairport, West Buffalo, and Rockingham;

To Davenport by $7 \mathrm{p} \mathrm{m}, 30$ miles;

And back between $5 \mathrm{a} \mathrm{m}$ and $12 \mathrm{~m}$.

4665 From West Liberty at $2 \mathrm{p} \mathrm{m}$, once a week, Saturday;

By Pedee,

To Rock Creek by $6 \mathrm{p} \mathrm{m}, 11$ miles;

And back between $9 \mathrm{a} \mathrm{m}$ and $1 \mathrm{p} \mathrm{m}$.

Proposals for twice a week service are invited.

4666 From lowa City at 4 a $\mathrm{m}$ daily, except Sunday;

By West Liberty and Overman's Ferry;

To Muscatine by $1 \mathrm{p} \mathrm{m}, 36$ miles;

And back between $12 \mathrm{~m}$ and $9 \mathrm{p} \mathrm{m}$.

4667 From Iowa City at 4 a $\mathrm{m}$ tri-weekly, Monday, Wednesday, and Friday;

By Yatton, Washington, Brighton, and Walnut;

To Fairfield by $9 \mathrm{p} \mathrm{m}, 56$ miles;

And back between $4 \mathrm{a} \mathrm{m}$ and $9 \mathrm{p} \mathrm{m}$ next days.

Proposals for six times a week service will be considered. 
4668 From Iowa City at 6 a m once a week, Thursday;

By Wasson's Mills, Houston's Point, and Sigourney;

To Lancaster by 11 a $\mathrm{m}$ next day, 50 miles;

And back between $1 \mathrm{pm}$ Friday and $6 \mathrm{p} \mathrm{m}$ next day.

4669 From Iowa City at 6 a m, twice a week, Monday and Thursday;

By Capi, Marengo, Montezuma, Newton and Parkersburg;

To Fort Des Moines by $6 \mathrm{p} \mathrm{m}$, next days, 80 miles;

And back between 6 a $\mathrm{m}$ Monday and Thursday and $6 \mathrm{p} \mathrm{m}$ next days.

Proposals for three times a week service will be considered.

4670 From Iowa City at 4 a in tri-weekly, Monday, Wednesday, and Friday;

By Solon, Hoosier's Grove, Cedar Rapids, Marion, Springville, Fairview, Anamosa, Monticello, Bowen's Prairie, and Cascade;

To Dubuque by $9 \mathrm{p} \mathrm{m}$ next days, 99 miles;

And back between 4 a $\mathrm{m}$ Monday, Wednesday, and Friday, and $9 \mathrm{p}$ m next days.

Proposals for six times a week service and to run through in 24 hours, will be considered.

4.671 From Iowa City at 6 a m, once a week, Tuesday;

By Gower's Ferry, Woodbridge, 'Tipton, Massillon, and Maquoketa ;

To Andrew by $8 \mathrm{p} \mathrm{m}$ next day, 67 miles;

And back between $6 \mathrm{a}$ m 'Ihursday and $8 \mathrm{p}$ m next day.

Proposals for twice a week service will be considered.

4672 From Washington at $9 \mathrm{a} \mathrm{m}$, once a week, Wednesday;

By Juan, Crooked Creek, and I'renton,

To Mount Pleasant by $6 \mathrm{p} \mathrm{m}, 25$ miles,

And back between $6 \mathrm{a} \mathrm{m}$ and $3 \mathrm{p} \mathrm{m}$ next day.

Proposals for twice a week service will be considered.

4.673 From $W$ ashington at $6 \mathrm{a} \mathrm{m}$, once a week, Wednesday,

By Dutch Creek, Pleasant Grove, Sigourney, Springfield, and Rose Hill;

To Oskaloosa by 11 a $\mathrm{m}$ next day, 53 miles;

And back between $1 \mathrm{p} \mathrm{m}$ Thursday and $6 \mathrm{p} \mathrm{m}$ next day.

4674. From Fairfield at 8 a m, twice a week, Tuesday and Friday;

By Libertyville, Iowaville, and Floris;

To Bloomfield by $6 \mathrm{p} \mathrm{m}, 33$ miles;

And back between 6 a $\mathrm{m}$ and $4 \mathrm{p} \mathrm{m}$ next days.

Proposals for three times a week service will be consideren.

4675 From Fairfield at $6 \mathrm{a} \mathrm{m}$, tri-weekly, Tuesdiy, Thursday, and Saturday;

By Libertyville, Ashland, Agency City, Ottumwa, Point Pleașant, and Eddyville;

To Oskaloosa by $9 \mathrm{p} \mathrm{m}, 48$ miles,

And back between $6 \mathrm{a} \mathrm{m}$ and $9 \mathrm{p} \mathrm{m}$ Monday, Wednesday, and Friday.

Proposals for six times a week service will be considered. 
4676 From Mount Pleasant at 4 a $\mathrm{m}$, once a week, Saturday, By Trenton and Deedsville,

To Brighton by $12 \mathrm{~m}, 22$ miles,

And back between $1 \mathrm{p} \mathrm{m}$ and $9 \mathrm{p} \mathrm{m}$.

4677 From Keosauqua, Iowa, at 9 a $\mathrm{m}$, once a week, Friday,

To Memphis, Missouri, by $6 \mathrm{p} \mathrm{m}, 26$ miles,

And back between $6 \mathrm{a} \mathrm{m}$ and $3 \mathrm{p} \mathrm{m}$ next day.

4678 From Keosauqua at $9 \mathrm{a} \mathrm{m}$, twice a week, Tuesday and Friday,

By Mechanicsburg, Oak Point, Fox, and Taylor,

To Bloomfield by $6 \mathrm{p} \mathrm{m}, 26$ miles,

And back between 6 a $\mathrm{m}$ and $4 \mathrm{p} \mathrm{m}$ next days.

Proposals for three times a week service will be considered.

4679 From Keosauqua at $5 \mathrm{a} \mathrm{m}$, twice a week, Tuesday and Saturday, By Rising Sun, Lick Creek, Portland, Iowaville, Ashland, and Agency City,

To Ottumwa by $9 \mathrm{p} \mathrm{m}, 43$ miles,

And back between $5 \mathrm{a} \mathrm{m}$ and $9 \mathrm{p} \mathrm{m}$ Monday and Friday.

Proposals to end at Agency City will be considered.

4680 From Bloomfield, Iowa, at 6 a mi, once a week, Tuesday,

By Fox, Oak Point, Union Corner, Chambersburg, Missouri, arid Waterloo,

To Alexandria by $6 \mathrm{p} \mathrm{m}, 70$ miles,

And back between $6 \mathrm{a} \mathrm{m}$ Thursday and $6 \mathrm{p} \mathrm{m}$ next days.

Proposals for twice a week service will be considered.

4681 From Bloomfield at 9 a $\mathrm{m}$, once a week, Wednesday,

To Centreville by $6 \mathrm{p} \mathrm{m}, 26$ miles,

And back between $6 \mathrm{a} \mathrm{m}$ and $3 \mathrm{p} \mathrm{m}$ next day.

Proposals to embrace Drakesville and Unionville are invited.

4682 From Bloomfield at 6 a $\mathrm{m}$ once a week, Monday,

By Drakesville, Avery, Albia, Princeton, Barkersville, Knoxville, and Three Rivers,

To Fort Des Moines by $6 \mathrm{p} \mathrm{m}$ next Wednesday, 106 miles,

And back between $6 \mathrm{a} \mathrm{m}$ Thursday and $6 \mathrm{p} \mathrm{m}$ next Saturday.

4683 From Ottumwa at 6 a $\mathrm{m}$ once a week, Wednesday,

By Village, Avery, and Unionville,

To Centreville by $6 \mathrm{p} \mathrm{m}, 40$ miles,

And back between $6 \mathrm{a} \mathrm{m}$ and $6 \mathrm{p}$ m next day.

4684 From Eddyville at $1 \mathrm{p} \mathrm{m}$ once a week, Tuesday,

By Half-way Prairie,

To Albia by $5 \mathrm{p} \mathrm{m}, 10$ miles,

And back between $8 \mathrm{a} \mathrm{m}$ and $12 \mathrm{~m}$.

4685 From Oskaloosa at 6 a m, once a week, Saturday,

By Auburn,

To Elm Grove by $12 \mathrm{~m}, 17$ miles,

And back between $1 \mathrm{p} \mathrm{m}$ and $7 \mathrm{p} \mathrm{m}$. 
4.686 From Oskaloosa at $8 \mathrm{a} \mathrm{m}$ once a week, Saturday,

By Scott and Durham's Ford,

'To Knoxville by 6 p m, 25 miles,

And back between $8 \mathrm{a} \mathrm{m}$ and $6 \mathrm{p} \mathrm{m}$, Friday.

Proposals to embrace Bellefontaine will be considered.

4687 From Oskaloosa at 4 a $\mathrm{m}$ tri-weekly, Monday, Wednesday, and Friday,

By Pella, Toole's Point, Red Rock, Bennington, Carr, and Apple Grove,

To Fort Des Moines by $9 \mathrm{p} \mathrm{m}, 60$ miles,

And back between $4 \mathrm{a} \mathrm{m}$ and $9 \mathrm{p}$ mext days.

Proposals for six times a week service will be considered.

4.i88 From Oskaloosa at 6 a m once a week, Tuesday,

By Warrensville,

To Newton by $6 \mathrm{p} \mathrm{m}, 35$ miles,

And back between $6 \mathrm{a} \mathrm{m}$ and $6 \mathrm{p} \mathrm{m}$ Monday.

4689 From Oskaloosa at 6 a m, once a week, Tuesday,

By Fremont, Freedom, Lancaster, Richland, and Clay,

To Brighton by $12 \mathrm{~m}$ next day, 54 miles,

And back between $1 \mathrm{p} \mathrm{m}$ and $6 \mathrm{p} \mathrm{m}$ next day.

Proposals for twice a week service are invited.

4690 From Fort Des Moines at 6 a m, once a week, Monday,

By Penoack, ${ }^{3}$

To Kane ${ }^{4}$ by 11 a m next Thursday, 150 miles,

And back between $2 \mathrm{p} \mathrm{m}$ Thursday and $6 \mathrm{p} \mathrm{m}$ next Sunday.

Proposals for more frequent trips will be considered.

4691 From Fort Des Moines at 6 a m, once a week, 'Tuesday;

By Indianola;

To Lancaster, Nissouri, by 6 p m next Friday, 125 miles;

And back between $6 \mathrm{a} \mathrm{m}$ Tuesday and $6 \mathrm{p}$ m next Friday.

4692 From Newton at $6 \mathrm{a} \mathrm{m}$, once a week, Monday;

To Washington by $6 \mathrm{p}$ m next Wednesday, 90 miles;

And back between 6 a $\mathrm{m}$ Thursday and $6 \mathrm{p} \mathrm{m}$ next Saturday.

4693 From Marion at 8 a m, once a week, Thursday;

By Palo and Alto;

To Vinton by $6 \mathrm{p} \mathrm{m}, 30$ miles;

And back between $6 \mathrm{a} \mathrm{m}$ and $4 \mathrm{p} \mathrm{m}$ Friday.

4694. From Marion at 7 a $\mathrm{m}$ once a week, Friday;

By Lafayette and Centre Point;

To Quasqueton, by $6 \mathrm{p} \mathrm{m}, 32$ miles;

And back between $6 \mathrm{a} \mathrm{m}$ and $5 \mathrm{p} \mathrm{m}$ next day.

sPenonch was the name first given to the county seat of Dallas County. which was changed to Adel in about 1850. See ANNals of Iows, "Abandoned Towns, Villages and Post Oflices of Iowa," Vol. XVII, page 465.

thane, the name of the post office at Kanesville, which was changed to Council bluffs in 1852. See ANNals of lowa, XVIII, page 64. 
4695 From Cedar Rapids at 6 a $\mathrm{m}$, once a week, Monday;

By Vinton;

To the falls of Cedar River by $6 \mathrm{p} \mathrm{m}$ next day, 70 miles;

And back between $6 \mathrm{a} \mathrm{m}$ Wednesday and $6 \mathrm{p} \mathrm{m}$ next day.

4696 From Quasqueton at $8 \mathrm{a} \mathrm{m}$, once a week, Friday;

By Independence;

To Sturges Rapids in Black Hawk county, by $6 \mathrm{p} \mathrm{m}$, 25 miles;

And back between $6 \mathrm{a} \mathrm{m}$ and $4 \mathrm{p} \mathrm{m}$ next day.

4697 From Tom Cowin, ${ }^{5}$ Iowa, at 6 a m, once a week, Wednesday;

To Prairie du Chien, Wisconsin, by 11 a m, 12 miles;

And back between $\tau \mathrm{a} \mathrm{m}$ and $8 \mathrm{p} \mathrm{m}$ next day.

4698 From Garnavillo at 6 a $\mathrm{m}$, once a week, Saturday;

To Elkader by $12 \mathrm{~m}, 18$ miles;

And back between $1 \mathrm{p} \mathrm{m}$ and $7 \mathrm{p} \mathrm{m}$.

4699 From Garnavillo, Iowa, at 5 a m, once a week, Thursday;

By Mendon and Manonah;

To Prairie du Chien, Wisconsin, by $12 \mathrm{~m}, 20$ miles;

And back between $1 \mathrm{p} \mathrm{m}$ and $7 \mathrm{p} \mathrm{m}$.

Separate proposals for route from Garnavillo to Prairie du Chien, and from Garnavillo by Mendon to Manonah will be considered.

4700 From Dubuque at $2 \mathrm{p} \mathrm{m}$, twice a week, Monday and Friday;

By Tete des Motte, Belleview, Wickliffe, Sabula, Elk River, Lyons,

Camanche, Princeton, Le Claire, and Pleasant Valley;

To Davenport by $8 \mathrm{p} \mathrm{m}$ next Wednesday and Sunday, 99 miles;

And back between $2 \mathrm{p} \mathrm{m}$ Monday and Friday, and $8 \mathrm{p} \mathrm{m}$ next

Wednesday and Sunday.

4.701 From Dubuque at 11 a m daily, except Sunday;

By La Motte, Andrew, Maquoketa, Dewitt, and Walnut Grove;

To Davenport by $4 \mathrm{a} \mathrm{m}$ next day, 74 miles;

And back between $4 \mathrm{a} \mathrm{m}$ and $10 \mathrm{p} \mathrm{m}$.

Proposals to extend this route and service through to Muscatine will be considered.

4702 From Dubuque at 6 a m, once a week, Thursday;

By Garry Owens, Canton, Tipton, Rock Creek, and Moscow;

To Muscatine by $6 \mathrm{p} \mathrm{m}$ next Saturday, 100 miles;

And back between 6 a $\mathrm{m}$ Monday and $6 \mathrm{p} \mathrm{m}$ next Wednesday.

Proposals for twice a week service will be considered.

4703 From Dubuque at $4 \mathrm{a} \mathrm{m}$, once a week, Saturday;

By Centretown, Whitewater, and Rockville;

To Delhi by $8 \mathrm{p} \mathrm{m}, 40$ miles;

And back between $4 \mathrm{a} \mathrm{m}$ and $8 \mathrm{p}$ m Friday.

Proposals for twice a week service will be considered.

5Evidently Tom Corwin, the name of the post office at Johnsonport which was a hamlet at an important landing on the Mississippi River in Allamakee

6Evidently Tete des Morts, now called St. Donatus, Jackson County. 
4704. From Dubuque at $4 \mathrm{a} \mathrm{m}$, once a week, Wednesday;

By New Vine and Tivoli;

To Colesburg by $8 \mathrm{p} \mathrm{m}, 40$ miles;

And back between $4 \mathrm{a} \mathrm{m}$ and $8 \mathrm{p} \mathrm{m}$, Tuesday.

Proposals to extend through to Fort Atkinson, increasing distance 45 miles, will be considered.

4705 From Dubuque at $5 \mathrm{a} \mathrm{m}$, once a week, Wednesday;

By Pin Oak, Millville, Guttenburg, and McGregor's Landing;

To Garnavillo by $7 \mathrm{p} \mathrm{m}, 46$ miles;

And back between $5 \mathrm{a} \mathrm{m}$ and $7 \mathrm{p} \mathrm{m}$ next day.

Proposals for twice a week service will be considered.

4706 From Delhi at 5 a $\mathrm{m}$ once a week, Monday;

By Coffin's Grove and Quasqueton;

To Independence by $7 \mathrm{p} \mathrm{m}, 40$ miles,

And back between $5 \mathrm{a} \mathrm{m}$ and $7 \mathrm{p}$ m next day.

Proposals to end at Quasqueton will be considered.

4707 From Fairview at 8 a $\mathrm{m}$ once a week, Friday;

By St. Mary's, St. Julian, and Ivanhoe;

To Solon by $4 \mathrm{p} \mathrm{m}, 24$ miles;

And back between $6 \mathrm{a} \mathrm{m}$ and $2 \mathrm{p} \mathrm{m}$ next day.

4708 From Tipton at 4 a m once a week, Wednesday;

By Spring Rock, Buena Vista, Dewit, and Lyons;

'To Fulton, Ill., by $12 \mathrm{~m}$ next day, 58 miles;

And back between $2 \mathrm{p} \mathrm{m}$ Thursday and $8 \mathrm{p}$ m next day.

4.709 From Tipton at 8 a $\mathrm{m}$ once a week, Friday;

By Ivanhoe, Pioneer Grove, and St. Julian;

'To Marion by $6 \mathrm{p} \mathrm{m}, 28$ miles;

And back between $6 \mathrm{a} \mathrm{m}$ and $6 \mathrm{p} \mathrm{m}$ next day.

4710 From Andrew at 8 a $\mathrm{m}$ once a week, Wednesday;

By Spring Brook and Bellevieu;

To Galena, Ill., by $6 \mathrm{p} \mathrm{m}, 29$ miles;

And back between $8 \mathrm{a} \mathrm{m}$ and $6 \mathrm{p} \mathrm{m}$, Tuesday.

\section{SPECIAL OFFICES.}

Proposals are invited for supplying the following offices in Iowa for the net proceeds of said offices respectively, limited to a sum to be named in the proposals in each case:

Augusta from Sand Ridge, 6 miles and back once a week.

Belle Fountain from Polk, 5 miles and back once a week.

Belle Point from Fort Des Moines, 30 miles and back once a week.

Bennington from Red Rock, 12 miles and back once a week.

Blue Grass from Davenport, 9 miles and back once a week.

Business Corner from Portland, 2 miles and back once a week.

Carleton from Fort Des Moines, 10 miles and back once a week.

From Chillicotha to Fountain Springs, - miles and back once a week.

Dahlonega from Sac and Fox Agency, 6 miles and back once a week.

Dẹnmark from Augusta, 6 miles and back once a week. 
Ead's Grove from Delhi, 10 miles and back once a week. Elkader from Garnavillo, 9 miles and back once a week. Elkport from Moreland, 12 miles and back once a week. Ewington from Postville, 5 miles and back once a week. Floris from Bloomfield, 6 miles and back once a week.

Hawk Eye from Yellow Springs, 7 miles and back, once a week. Independence from Fort Des Moines, 30 miles and back once a week. Indianolo from Fort Des Moines, 23 miles and back once a week. Kirkville from Fountain Springs, 5 miles and back once a week. Lovelia from Albia, 9 miles and back once a week.

Maryville from Centre Point, 7 miles and back once a week.

Montacute from Apple Grove, 14 miles and back once a week. New Holland from Lagro, 6 miles and back once a week.

Nine Eagles from Princeton, 20 miles and back once a week. Paran City from Red Rock, 6 miles and back once a week.

Portland from Business Corners, 2 miles and back once a week. Port Louisa from 'Toolesboro', 11 miles and back once a week.

Salt Lake, California, from Kane, 1,030 miles and back six times a year.

South Fork from Centreville, 14 miles and back once a week.

Spragueville from Spring Brook, 7 miles and back once a week.

Union Mills from Oskaloosa, 12 miles and back once a week.

Walnut Fork from Fairview, 14 miles and back once a week.

Wells's Mills from Bloomfield, 20 miles and back once a week.

Yankee Settlement from Colony, 17 miles and back once a week.

\section{IOWA SALT}

It is not perhaps generally known that there are numerous indications of the existence of salt in this territory, and particularly in the region of country bordering on the Des Moines River, yet such is the fact. We are glad to learn that these indications are about being tested. A friend has just informed us that a company of gentlemen acquainted with the manufacture of salt have commenced boring at the flourishing town of Bonaparte, Van Buren County, and that they are confident of succeding in their enterprise. We hope they may.-Territorial Gazette (Burlington), quoted in the Bloomington (Muscatine) Herald, May 10, 1844, p. 2, c. 6. (In the Newspaper Division of the Historical, Memorial and Art Division of Iowa.) 
Copyright of Annals of Iowa is the property of State of Iowa, by \& through the State Historical Society of Iowa and its content may not be copied or emailed to multiple sites or posted to a listserv without the copyright holder's express written permission. However, users may print, download, or email articles for individual use. 